\title{
COÖPERATION BETWEEN STATE HORTICULTURAL INSPECTORS
}

\author{
By A. W. Morrilu, Phoenix, Ariz.
}

It is not the writer's intention to present in this paper a comprehensive scheme for coöperation among those in charge of state horticultural inspection affairs. Rather he frankly confesses to the narrowness of his experience in this line of work and to his lack of a thorough knowledge of the problems of most of his fellow-workers in other states. This paper is prompted principally by certain problems which confront the inspection service in Arizona-problems, however, which are not peculiar to Arizona, but which the writer is prepared to discuss particularly from the standpoint of the arid southwest.

During the first year's operation of the Horticultural Inspection law in Arizona, the records of our inspection of imported plants showed 8.6 per cent of the shipments from other states to be infested with insect pests. The second year's operation showed a decrease in infested shipments to 6.4 per cent and the third year's to 4.2 per cent. The writer believes he is not ungencrous in ascribing this improvement of conditions not to a reduction in the numbers of insect pests in the nurserics and other plant shipping establishments or to increased efficiency of the officials in other states, who furnished the certificates of inspection, but to the simple spread of knowledge among nurserymen, florists and other plant shippers concerning Arizona's requirements. It is our experience that it is important that information be placed in the hands of not only those who are now shipping plants into the state but those who may do so in the future, in order that they may comply with our requirements, or if impossible to do this, that they may protect themselves by refusing orders from our state. The fact that we propose to inspect all shipments of plants coming into the state affects only in a degree the desirability of having infested shipments kept out. In spite of the best endeavors on the part of common carriers to keep all of their new, as well as old employees informed concerning the matter of holding plants for inspection, occasionally a shipment will be delivered without awaiting for the inspector's release. This is especially likely to occur when the packages, boxes or bundles are not properly labeled to indicate the true contents. It is therefore important, as a matter of protection, that every practicable effort be made to reduce the number of infested shipments entering a state even in the case of those states where shipments of plants are inspected at destination. 


\section{Means for Informing Shippers of Plants Concerning State REQUIREMENTS}

In this connection, the writer proposes that this Association provide for an annually revised circular of information containing, in as concise form as practicable, the exact requirements of each state, which are of interest to shippers of plants, and agricultural and horticultural products. The information should include the restrictions imposed by state quarantine orders and for each state should be prepared for inclusion in the circular suggested, by the official in charge of the plant inspection service. Such a circular might appear as a revision of circular No. - of the Bureau of Entomology, providing arrangements for coöperation with the United States Department of Agriculture can be made. In this case, the restrictions upon interstate and international shipments of plants by the National Plant Quarantine Act and by the Quarantine Orders issued by the Federal Horticultural Board might perhaps with advantage be included in the same publication.

It is essential, the writer believes, that such a circular, to serve its greatest usefulness, be revised annually and be issued with regularity on or about October first of each year. The issuance of such a circular would not, however, in itself, fulfill the desired object of placing the information in the hands of those principally concerned. A mailing list for the distribution of the circular should be maintained under the supervision of the secretary of this organization, made up of lists of nurserymen and florists doing an interestate business to be furnished by the officials in charge of the plant inspection matters in the various states. Such a mailing list would, of course, need annual revision.

Need and Means for Better Coördination of Efforts of State Plant Inspection Officials.

Practically all of the state horticultural laws require a certificate of inspection from the shipper's home state as a condition for the acceptance of nursery stock importations. Experience in those states where inspections of the shipments are made at destination shows that as a measure of protection this requirement fails utterly to accomplish the desired object. Under present conditions it is even harmful in one respect-it hinders and delays the spread of the system of inspection at destination which has been adopted by only a few states, but which is destined to become general. The additional requirement of some states of fumigation of nursery stock as a condition of entry is, in the writer's opinion and experience, of very little value as far as stock admittedly infested in any degree is concerned.

Arizona, with its insufficient supply of home grown nursery stock 
and with its population of more than ordinary cosmopolitan origin, receives nursery stock and other plant supplies from nearly every state in the country. The figures presented in the introduction of this paper for the first season's operation of the inspection law indicate that where the shippers are not fully aware that inspection at destination is practiced, nearly nine shipments out of 100 are actually infested in some degree by injurious insects; moreover these infested shipments are each accompanied by a certificate declaring that the shippers stock has been duly inspected within a year and found free from injurious insects.

The writer has several times been moved to attempt to preserve the dignity of the plant inspection profession by explaining that some insects, although admittedly injurious, are so widely distributed in some sections of the country that further attempts to prevent their spread by means of nursery stock in such sections are of comparatively little value. Let us, however, consider the Eastern peach tree borer. Are there not even in the most generally infested Eastern states, fruitgrowing sections, or sections which are yet undeveloped, where this pest does not exist? And is it not the duty of nursery inspectors to give consideration to the protection of such sections.

Dr. O. C. Bartlett, assistant state entomologist of Arizona, formerly deputy inspector in Massachusetts, informs me that in the latter state there are sections which need protection against the common peach tree borer. Doubtless this is true also of practically every state in the East. In the far West, however, the Eastern peach tree borer is very limited in its distribution and in Arizona and neighboring states there is just as much reason to exclude this pest as the San José scale.

Shipments of peaches, plum and apricot trees infested to a greater or less degree by the Eastern peach tree borer have been received in Arizona during the past three years from at least five states located north and east of us. In one case a shipment of about 3,000 peach trees which appeared to be the infested discard of a nursery was received at Phoenix. In this case a certificate supposed to show that the trees had been free from injurious insects when inspected in the nursery, accompanied the shipment of trees which were not only infested, but for the most part virtually killed by insect pests. Trees killed by San José scale could not have been of less value than these girdled peach trees. When notified that the shipment either must be burned or must be reshipped, the nurserymen wired that they expected their "certificate to protect them." Needless to say, it did not. Is it not important that state inspectors, for the sake of their reputations, and honest nurserymen, for the sake of their business, be protected against such an abuse of official inspection certificates? 
The writer considers the most important matter confronting this association is the coördination of the work of the state inspection officials throughout the country in order to accomplish the greatest measure of success in preventing the spread of insect pests. Doubtless each member of this Association has ideas upon this subject. The ideas to be presented here are offered as a basis for coördination, which at present is almost entirely lacking, for the accomplishment of the above purpose.

First. We should make this a more effective organization of official horticultural inspectors by securing the enrollment and active interest of the inspection officials in charge in those states not now represented and furthermore we should make this organization a center for active coöperation instead of maintaining it primarily for the purpose of holding annual meetings, however helpful such meetings may be even without further activity for 363 days in the year.

Second. We need a uniform system of nursery and plant certification. Certificates of inspection should mean more than the destination inspections made in some states show them to mean. Assuming that the nursery inspectors in each state make full reports to their chief of all insects injurious or likely to become injurious found in each nursery inspected and assuming that these records are filed, could not a simple system be devised for furnishing the head inspection official in all other states a sworn statement of the actual condition of each nursery as regards insect pests? If the findings show the nursery absolutely free from insect pests, let the certificate be issued in accordance therewith, otherwise I propose that for interstate shipments a certificate be used which will state plainly that the nursery has been found free from pests with certain exceptions filed with the officials in charge of plant inspections in every state in the country, also that the nurserymen accepting and using the certificate has agreed to use every reasonable precaution against including any infested stock.

In cases where such a special certificate is issued, the nurserymen should be bound to assume his full share of the responsibility in the matter. For example in the case of the Eastern peach borer, certificates might fairly be issued with the agreement that they are revokable upon the presentation of proof to the chief inspector that such a certificate has been used on a shipment in which more than one susceptible fruit tree in five hundred contained a live borer. Similar arrangements could be made in the case of the woolly apple aphis, perhaps providing for special exterminative treatments in this case. The patrons of the nurserymen concerned could well afford to have added to their bills the slight expense occasioned by such arrangements. If all the states having provisions for nursery inspections 
would adopt this uniform system, no honest nurseryman could complain of unfair treatment in the matter.

If such a plan of coöperation as proposed were adopted, much of the clerical work could be economically centralized through this organization. A fixed annual assessment not exceeding $\$ 10$ for each state would allow a remuneration for the supervisory, and other work of the secretary and pay for all clerical assistance that may be needed.

Is it not both practicable and timely for this organization to consider, endorse and actively promote some plan to standardize the value of certificates of nursery inspection?

\section{WHAT BESIDES INSPECTION?}

By H. A. Sunface, Harrisburg, $\mathrm{Pa}$.

In the official performance of our duties as inspectors, we often feel that more can be done for mankind than mere inspection of property of an owner and notifying him of the absence or presence of pests and means of suppressing them. I do not think there is a worthy member of this association who in his inspection work does not go beyond the mere formalities above mentioned. As officials guarding the welfare of the public, no doubt we all take the new, modern and practical view that "prevention is better than remedy." Note how our health departments and sanitary commissions are turning their attention toward not only the eradication of diseases, but especially their prevention. In fact, all of us who are engaged in the important work of inspection realize that the detection of pests through this service is chiefly for the purpose of preventing their dissemination and, therefore, the work is more preventive than curative. The grower of trees or plants who receives the benefit of this service little realizes what it really means. Without it he would be invaded by pests such as he has not before known, and hence of species that he would not recognize until the damage might be irreparable, or their eradication or suppression accomplished only by extremely expensive means.

We know full well that there are many very serious insects and plant diseases that may yet reach our respective states, and fortunately, for our citizens, have not yet made their appearance within our borders. Can we expect to keep out some of these pests, many of which are more terrible than any we now know, by our own efforts at inspection work, however thorough it may be?

It is always important to know what others are doing in their respective fields, and compare notes in order to adopt the best methods 